\title{
INDUSTRI RUMAH TANGGA STICK WORTEL DI DELI SERDANG
}

\author{
Siti Sutanti $^{*}$, Erli Mutiara ${ }^{1}$ \\ ${ }^{1}$ Jurusan Pendidikan Kesejahteraan Keluarga, Fakultas Teknik, Universitas Negeri Medan, \\ Jl. Willem Iskandar pasar V-Kotak Pos No. 1589 - Medan 20221 \\ *Penulis Korespodensi: erli_mutiara@yahoo.co.id
}

\begin{abstract}
Abstrak
Stick adalah camilan yang disenangi karena rasanya yang gurih. Stik di buat dengan berbagai rasa, salah satunya rasa wortel. Mitra kegiatan yaitu usaha industri rumahtangga Mekar Mandiri dan usaha industri rumahtangga Merpati Putih di Kecamatan Tanjung Morawa. Tujuan Kegiatan ini pengembangan usaha pengolahan stick wortel. Kegiatan dilaksanakan 8 bulan tahun 2016. Metode Pelaksanaan melalui pendidikan, pelatihan produksi, pelatihan manajemen usaha, penggunaan mesin dan pendampingan. Target luaran yaitu : a) mesin pencetak stick wortel; b) stick wortel. Hasil kegiatan yang diperoleh adalah mitra mampu memproduksi stick wortel. Mitra dapat mengoperasikan mesin pencetak stick wortel dengan baik. Produksi mitra semakin banyak dan omset mitra semakin bertambah.
\end{abstract}

Kata kunci: Stick, Wortel, Industri, Rumahtangga

\begin{abstract}
Stick is a favorite snack because it tastes savory. Sticks are made with a variety of flavors, one of which is the taste of carrots. Activity Partners are home industry of Mekar Mandiri and Merpati Putih household business in Tanjung Morawa sub district. The purpose of this activity is the development of carrot stick processing business. Activity is implemented 8 months in 2016. Method Implementation through education, production training, business management training, machine use and assistance. Output targets are: a) carrot sticking machine; B) carrot sticks. The results of the activities obtained are the partners are able to produce carrot sticks. Partner can operate the carrot sticking machine well. Partner production is growing and partner turnover is growing.
\end{abstract}

Keywords: Stick, Carrot, Industry, Household

\section{PENDAhUluan}

Wortel merupakan sayuran yang multi khasiat bagi kesehatan masyarakat. Di Indonesia wortel dapat dianjurkan sebagai bahan pangan potensial untuk mengentaskan masalah penyakit kurang vitamin A karena kandungan karoten (pro vitamin A) pada wortel dapat mencegah penyakit rabun senja (buta ayam) dan masalah kurang gizi. Beta karoten di dalam tubuh akan diubah menjadi vitamin A, zat gizi yang sangat penting untuk fungsi retina (Astarina, 2010).

Wortel merupakan jenis sayur yang sering dikonsumsi masyarakat. Komoditi ini tergolong sebagai sayuran sumber serat makanan yang tinggi. Wortel juga merupakan makanan sumber antioksidan alami. Wortel mudah diperoleh dan harganya murah (Astarina, 2010).

Wortel merupakan sejenis sayuran akar yang terbenam di dalam tanah, sementara daunnya menjulang ke atas permukaan tanah. Wortel (Daucus carota) adalah tumbuhan sayur yang ditanam sepanjang tahun, terutama di daerah pegunungan yang memiliki suhu udara dingin dan lembab, kurang lebih pada ketinggian 1200 meter di atas permukaan laut. Wortel dapat tumbuh di daerah yang tanahnya gembur, subur dan kaya akan humus. Tidak disembarang tanah yang biasa ditumbuhi tanaman wortel. Tapi wortel juga dapat tumbuh di daerah yang kurang subur dan miskin humus, dengan cara pemupukan yang intensif, baik dan benar. Wortel membutuhkan tempat yang sejuk untuk pertumbuhan terbaiknya. Wortel dapat di tanam pada bagian ujung batangnya dan pada bagian bawah wortel. Wortel tumbuh di dalam tanah (tertanam) sebagai umbi akar. Umbi akar ini dapat ditanam lagi dan bisa menghasilkan buah wortel yang baru (Nisa, 2009).

Kandungan wortel yang terdiri atas sebagian besar zat yang bernama beta karoten, yang membuat wortel berwarna jingga terang yang indah dan menawan. Zat tersebut dikenal akan menjadi vitamin A 
setelah dicerna oleh tubuh. Selain beta karoten, kandungan wortel lainnya adalah banyak mengandung serat, zat antioksidan, vitamin (C dan B kompleks), serta beberapa mineral penting seperti kalsium, zat besi, magnesium, fosfor dan sodium (Aguskrisno, 2011).

Manfaat wortel bagi kesehatan yaitu mencegah penyakit kanker, dapat menyehatkan kulit, menjaga kesehatan mata, membuat awet muda, mampu mencegah stroke. Wortel juga bermanfaat untuk menurunkan kloesterol, mencegah penyakit jantung , dalam Daftar Komposisi Bahan Makanan (DKBM) bahwa setiap $100 \mathrm{~g}$ bagian wortel yang dapat dimakan mengandung $\beta$-karoten sebanyak 12.000 SI (Wijaya, 2013).

Wortel merupakan komoditi sayuran yang termasuk dalam golongan klimaterik yaitu sayuran yang menunjukkan peningkatan respirasi yang tinggi setelah di panen. Peningkatan repirasi menyebabkan wortel mudah mengalami kerusakan seperti pelayuan bahkan sampai pada pembusukan (Pantastico, 2012).

Oleh karena itu perlu penanganan khusus untuk memperpanjang masa simpan wortel. Salah satu yang perlu dilakukan dengan penerapan teknologi tepat guna dalam pengolahan wortel.

Sebagian besar masyarakat Indonesia selama ini belum memanfaatkan wortel secara optimal, wortel hanya dimanfaatkan dalam pengolahan sayur seperti sup, urap, trancam, dll. Rasa wortel yang tidak disukai oleh anak-anak juga mengakibatkan jenis sayuran ini jarang dikonsumsi oleh anak-anak. Wortel segar mempunyai flavour langu sehingga kurang disukai konsumen. Akibatnya pemanfaatan komoditi ini masih terbatas. Wortel dapat diolah lebih lanjut antara lain dibuat snack dalam bentuk stick wortel matang yang kaya akan provitamin A. (Astarina, 2010).

Stick adalah camilan yang disenangi karena rasanya yang gurih. Tidak berbeda dengan penganan ringan lainnya, stick dianggap sebagai makanan selingan atau camilan teman minum teh atau sebagai teman bagi makanan lainnya. Stik dapat di buat dengan berbagai rasa, salah satunya rasa wortel.

Wortel sangat mudah temukan di berbagai pasar tradisonal di Kota Medan, dengan harga yang begitu murah jika saat musim panen raya. Berdasarkan hal tersebut maka perlu memberikan pelatihan kepada mitra untuk menambah variasi usahanya. Salah satu upaya yang perlu dilakukan adalah memberikan pendidikan, sosialisasi, pelatihan produksi dan manajemen usaha guna meningkatkan penghasilan mitra. Upaya yang dapat dilakukan adalah pengolahan wortel menjadi stick wortel sehingga setiap saat dapat dikonsumsi oleh masyarakat yang dapat meningkatkan kesehatan dan perbaikan gizi terutama untuk anak-anak yang sangat membutuhkan vitamin A untuk mencegah berbagai penyakit.

\section{BAHAN DAN METODE}

Metode Pelaksanaan yang dilakukan dalam kegiatan ini adalah metode pendidikan, metode pelatihan produksi, pelatihan manajemen usaha, penggunaan alat dan pendampingan. Berikut ini metode pelaksanaan dan penyelesaian permasalahan mitra yang akan dilaksanakan :

\section{Produksi}

Mitra kegiatan ini terdiri dari 2 mitra yaitu usaha industri rumahtangga Mekar Mandiri dan usaha industri rumahtangga Merpati Putih yang berada di Kecamatan Tanjung Morawa berjarak $20 \mathrm{~km}$ dari Unimed, merupakan salah satu kelompok usaha yang memproduksi kue bawang. Kelompok usaha ini menggunakan bahan baku dari tepung terigu, dalam pengolahan kue bawang perharinya bisa mencapai 50 kg. Peralatan yang digunakan untuk mengolah kue bawang masih sederhana, seperti untuk pencetakan kue bawang mitra masih menggunakan ampia kecil manual. Kue bawang ini dikemas dalam kemasan platik kecil dengan harga $\mathrm{Rp} 500$,- dan isi $1 \mathrm{~kg}$ harga jualnya $\mathrm{Rp}$ 25.000,-. Hasil usaha ini ini digemari oleh masyarakat karena rasanya yang gurih dan harganya juga dapat dijangkau terutama anak-anak. Sistem pemasarannya masih terbatas, hanya dititipkan di warung-warung, dijual di pasar tradisional, di jual oleh pedagang kaki lima yang ada di sekitar sekolahan dan terkadang dijual kepada pengumpul. Keberadaan usaha kue bawang ini sebenarnya sangat menguntungkan bagi masyarakat sekitarnya karena dapat menyerap tenaga kerja sekitar 4-10 orang. Pekerja pada kelompok usaha kecil ini merupakan pekerja lepas atau pekerja harian dengan gaji perhari Rp 15.000,- perorang.

Berdasarkan kondisi mitra tersebut, yang menjadi permasalah mitra adalah diperlukannya teknologi tepat guna yaitu alat pencetak stick wortel dengan menggunakan mesin dan pengembangan produk yaitu stick wortel sehingga dapat memproduksi stick semakin banyak, dengan menggunakan teknologi tepat guna, murah dan mudah untuk melakukannya.

\section{Manajemen}

Bila dilihat kondisi manajemen yang diterapkan oleh mitra industri rumahtangga ini masih menggunakan manajemen sederhana secara kekeluargaan, dimana pengelolaan administrasi yang meliputi pengaturan kerja, pembiayaan, produksi dan SDM masih dilakukan secara sederhana. Untuk pengelolaan usaha mitra ini, semuanya masih di pegang oleh pemilik usaha, baik pengadaan bahan baku, pengelolaan produksi, tenaga kerja, dan penjualan. Meskipun menganut manajemen kekeluargaan, sistem pembagian kerja sudah teroganisir dengan baik, artinya masing-masing pekerja sudah mempunyai tugas dan tanggungjawab untuk pekerjaan masing-masing.

Melihat potensi kelompok usaha mitra ini cukup besar dan didukung dengan potensi sumberdaya alam. Mudahnya mendapatkan bahan baku disekitar tempat tinggal mitra kiranya diperlukan suatu upaya untuk memberdayakan kelopok usaha ini. Melalui teknologi tepat guna dan memberikan pengetahuan, pelatihan produksi, manajemen usaha dan pemasaran. Kegiatan yang dilakukan yaitu memberikan 
pengetahuan tentang kandungan gizi wortel, teknik pengolahan wortel menjadi stick wortel. Produk usaha stick wortel ini akan menghasilkan stick yang berkualitas, gizi tinggi yang dapat mengurangi biaya produksi, sehingga dapat meningkatkan pendapatan kelompok usaha mitra.

\section{Persoalan Prioritas Mitra}

Berdasarkan pengamatan langsung dan wawancara dengan mitra industri rumahtangga stick wortel (11 Maret 2015), mereka menyatakan permasalahannya dalam hal produksi yaitu pengembangan produk kue bawang menjadi stick wortel. Usaha industri rumahtangga stick wortel ini belum memiliki peralatan (teknologi tepat guna) berupa mesin pencetak stick wortel, dan manajemen usahanya masih sederhana. Berdasarkan bukti konkret berupa data-data, terus mengalami perkembangan sesuai dengan permintaan pasar. Hal inilah yang harus ditangani agar usaha ini lebih berkembang.

\section{Metode Pendekatan yang ditawarkan}

Berdasarkan permasalahan yang telah dikemukakan, maka dalam kegiatan ini metode pendekatan yang digunakan adalah metode pendidikan, metode pelatihan produksi, pelatihan manajemen usaha, penggunaan mesin dan pendampingan. Dari permasalahan yang telah dikemukakan, dan untuk mencapai tujuan yang diharapkan, metode pendekatan yang ditawarkan untuk memecahkan masalah tersebut secara operasional adalah sebagai berikut :

1. Memberikan pengetahuan tentang kandungan zat gizi stick wortel dengan metode pendidikan dan penyuluhan pada kelompok usaha mitra. Stick wortel mempunyai kandungan gizi karbohidrat, vitaman A dan serat tinggi, sehingga di mungkinkan untuk diolah menjadi produk pangan.

2. Memberikan teknologi pengolahan pangan untuk dijadikan stick wortel yang aman untuk dikonsumsi, dengan metode pendidikan, penyuluhan dan pelatihan produksi. Tujuan pelatihan produksi ini, memberikan pengetahuan kepada mitra, teknik pengolahan stick wortel, sanitasi dan higiene makanan untuk meningkatkan mutu dan keamanan pangan, sehingga dapat di jadikan peluang pengembangan usaha.

3. Memberikan mesin pencetak stick wortel dan metode pendampingan penggunaan mesin pencetak stick wortel pada mitra. Mesin ini efektif dan efisien, operasinya mudah, sehingga dapat mencetak stick wortel dengan cepat.

4. Memberikan teknik pengolahan stick wortel dan keamanan pangan dengan metode sosialisasi dan pelatihan produksi. Makanan yang di produksi dengan tujuan untuk dijual kepada masyarakat umum, seharusnya dijamin mutunya baik serta aman untuk dikonsumsi.

5. Memberikan pelatihan manajemen usaha, dengan tujuan untuk meningkatkan keterampilan pemilik usaha (mitra) dalam menerapkan manajemen di bidang organisasi, produksi, keuangan, administrasi, harga jual produk, konsumen dan teknik pemasaran. Pelaku usaha ini biasanya adalah pemilik usaha yang memiliki fungsi ganda, karena itu manager dalam usaha ini berhadapan langsung dengan semua hal yang berkaitan dengan usaha, produksi, sumberdaya, pemasaran, pengembangan usaha dan lain-lain.

\section{Prosedur Kerja}

Prodesur kerja yang akan dilakukan untuk mendukung realisasi metode yang di tawarkan sebagai berikut :

1. Memberikan pendidikan tentang kandungan gizi dan manfaat stick wortel

2. Memberikan pelatihan penggunaan mesin pencetak stick wortel

3. Memberikan pelatihan produksi stick wortel.

4. Memberikan pelatihan manajemen usaha yaitu teknik perhitungan laba, pembukuan, peningkatan usaha dan pemasaran.

\section{HASIL DAN PEMBAHASAN}

Kenyataan dalam kehidupan sehari-hari kebutuhan hidup manusia tidak terlepas dari konsumsi sayuran. Namun, sampai saat ini masih banyak yang tidak menyukai sayuran karena cara pengolahannya yang cenderung monoton sehingga membuat orang merasa bosan, misalnya wortel. Seperti yang telah kita ketahui bahawa wortel merupakan bahan pangan yang bergizi tinggi dan harganya terjangkau oleh seluruh lapisan masyarakat. Banyak orang mengenal manfaat wortel hanya pada vitamin A-nya saja. Padahal wortel mempunyai kandungan zat-zat yang bermanfaat bagi tubuh. Diantaranya kandungan wortel ini ada gula, karotin, pectin, aspargin, vitamin A, B, C, D dan vitamin $\mathrm{K}$, serat, lemak, hidrat arang, kalsium, posfor, besi, sodium, asam amino minyak esensial dan betakarotin (Pribadi Halim, 2014).

Pemanfaatan wortel tidak hanya dapat dinikmati dalam bentuk segar ataupun pelengkap makanan. Tetapi banyak cara lain sebagai langkah inovasi pengolahan wortel yang menarik dan bercita rasa tinggi. Tingginya persentase wortel yang dimakan serta manfaat dari wortel yang besar kurang diimbangi dengan upaya pemanfaatan yang optimal. Sebagian orang mengolah wortel hanya sekedar dicampurkan dalam makanan sehari-hari, padahal dengan kandungan senyawa yang dimiliki dapat dilakukan suatu teknik pengolahan untuk mengubah wortel menjadi aneka produk yang bisa dikonsumsi setiap saat (Pribadi Halim, 2014).

Saat ini, usaha penganekaragaman pangan (ketahanan pangan) sangat diperlukan sebagai usaha untuk mengatasi masalah ketergantungan pada satu produk pangan pokok saja. Misalnya dengan mengolah umbi-umbian menjadi berbagai bentuk makanan yang mempunyai rasa khas dan tahan lama untuk disimpan. Berbagai bentuk olahan tersebut 
dapat berupa tepung, keripik, jus, dan stik (Pribadi Halim, 2014).

Stik merupakan makanan ringan atau cemilan berupa irisan tipis menyerupai mie yang sangat populer dikalangan masyarakat karena sifatnya yang renyah, gurih dan tidak terlalu mengenyangkan serta tersedia dalam aneka rasa seperti asin, pedas dan manis. Stik sangat praktis karena kering, sehingga lebih tahan lama dan mudah disajikan. Stik terbuat dari berbagai macam buah-buahan atau sayuran seperti wortel. Karakteristik dari stik wortel adalah bertekstur renyah (crunchy). Untuk mendapatkan tekstur yang renyah maka ditambahkan tepung terigu sebagai bahan perekat dan bahan tambahan lain seperti telur, tepung beras dan margarin agar mendapatkan tekstur yang renyah (Pribadi Halim, 2014).

Kegiatan ini merupakan suatu kegiatan pengabdian kepada masyarakat, yang secara langsung bersama-sama mitra menangani permasalah yang dihadapi serta membantu menyelesaikan persoalan mitra dengan pendekatan multi disiplin ilmu. Kegiatan yang dilakukan diawali dengan pertemuan tim pelaksanan untuk pembagian tugas masing-masing tim pelaksana. Kemudian penetapan jadwal pelaksanaan kegiatan baik dari LPM dan mitra. Selanjutnya tim pelaksana melakukan pengurusan perijinan.

Dengan tersusunnya jadwal kegiatan, maka tim pelaksana melaksanakan tugas sesuai dengan yang sudah disepakati. Selanjutnya tim pelaksana melakukan pembelian bahan dan peralatan yang dibutuhkan untuk kegiatan. Pada gambar 1 dapat dilihat mesin pencetak stick yang diberikan kepada mitra.

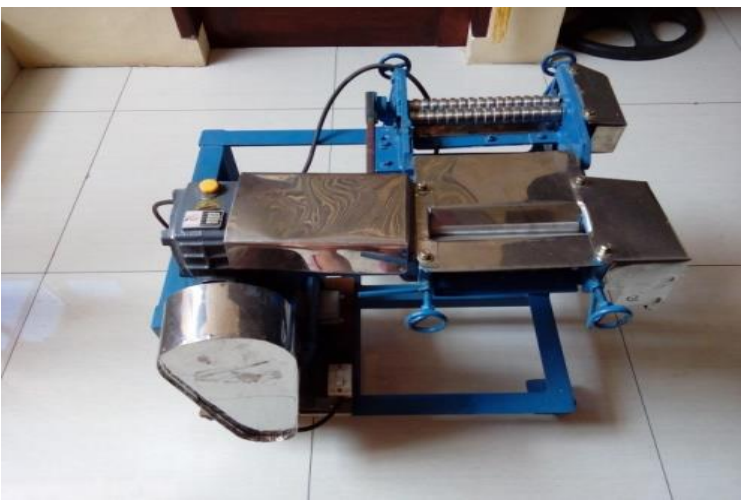

Gambar 1. Mesin pencetak stick wortel untuk mitra 1

Langkah berikutnya setelah dilakukan koordinas dan sosialisasi, yaitu mengadakan pelatihan cara membuat stick wortel serta menggunakan mesin pemotong stick wortel. Sebelum dilakukan praktek pembuatan membuat stick wortel terlebih dahulu dilakukan penyerahan alat-alat dan bahan bahan baku kepada mitra disaksikan oleh tim dari LPM Unimed dan perangkat Kelurahan. Penyerahan alat-alat dan bahan baku secara simbolik dilakukan oleh Ketua Tim pelaksana dan diterima oleh Mitra. Pada gambar 2 dan 3 dapat dilihat serah terima alat kepada mitra.

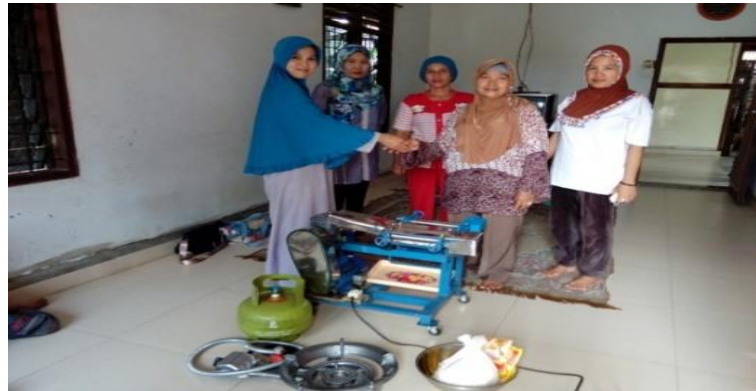

Gambar 2. Serah terima mesin pencetak dan peralatan kepada mitra 1

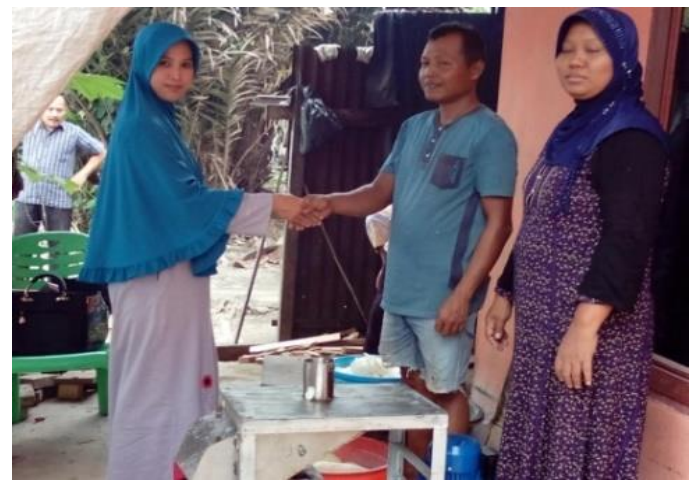

Gambar 3. Serah terima mesin pemotong kripik kepada mitra 2

Pada kegiatan pelatihan membuat membuat stick wortel, kegiatan diawali dengan penjelasan teori terlebih dahulu. Setelah teori diberikan kepada peserta selanjutnya diadakan tanya jawab untuk membahas halhal yang dirasa belum dipahami oleh peserta. Setelah teori dipandang cukup dipahami oleh peserta selanjut diadakan kegiatan praktik membuat membuat stick wortel. Setelah pelatihan dengan materi teori dipandang sudah cukup dan peserta sudah paham semua maka kegiatan berikutnya adalah dan praktik membuat membuat stick wortel.

Bahan yang di gunakan untuk membuat stick wortel adalah Tepung terigu $800 \mathrm{gr}$, wortel yang sudah dikukus dan dihaluskan sebanyak 200 gr, telur 2 butir di kocok lepas, garam 20 gr, margarine 100 gr, Royco saset 1 bungkus, gula pasir 1 sendok makan dan keju parut 150 gr serta minyak goreng untuk menggoreng stick wortel. Cara membuatnya, semua bahan di campur lalu diaduk rata sampai kalis selanjutnya di cetak menggunakan mesin pencetak stick wortel. Setelah selesai di cetak masukkan minyak goreng ke dalam wajan, dipanaskan lalu masukkan stick goreng sampai kuning cerah lalu angkat dan tiriskan. Selanjutnya setelah dingin kemas dengan plastik dan di tempelkan lebel pada kemasan. Pada gambar 4 dapat dilihat mitra sedang membuat stick wortel. Gambar 5 hasil produksi stik wortel dan gambar 6 lebel yang digunakan untuk kemasan stick wortel. 


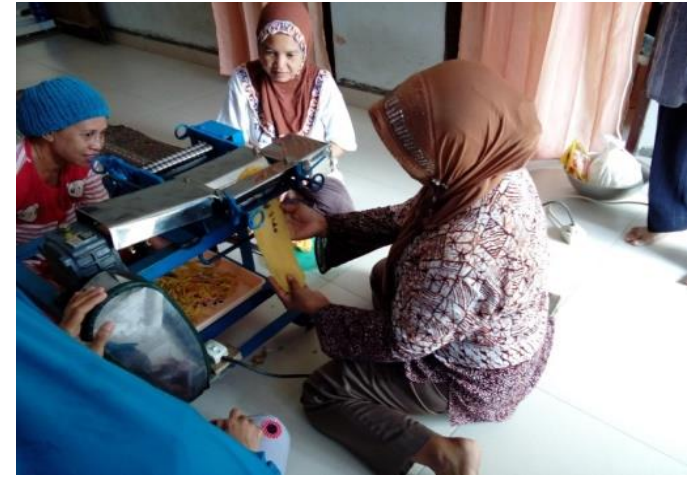

Gambar 4. Mitra 1 sedang mengoperasikan mesin pencetak stick

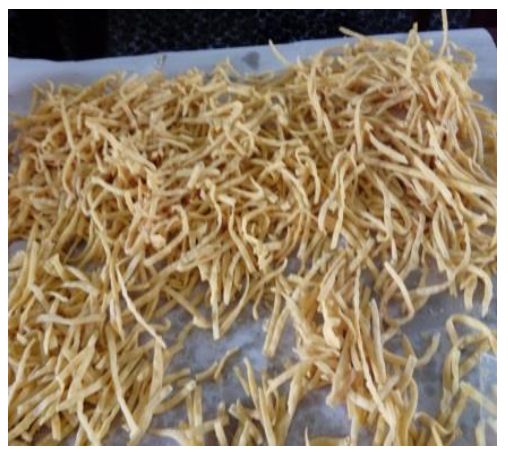

Gambar 5. Stick wortel yang sudah di goreng

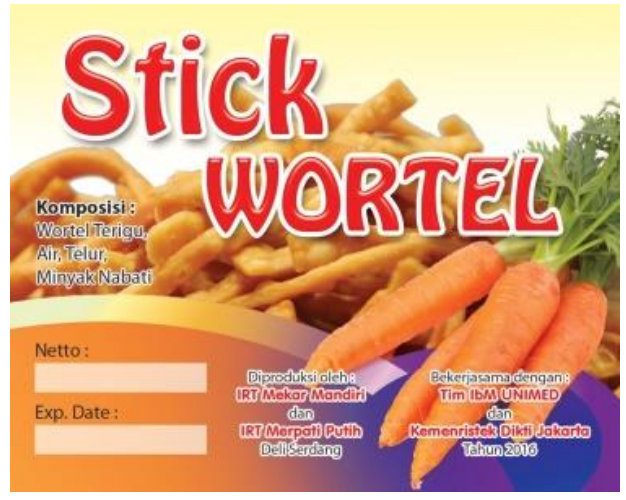

Gambar 6. Lebel stick wortel

Hasil praktek pelatihan adalah berupa produk membuat stick wortel yang perlu mendapat penilaian dari Tim pelaksana. Penilaian terhadap kualitas produk didasarkan pada pedoman acuan yang telah ditetapkan oleh Tim Pelaksana. Secara umum kegiatan ini berhasil dengan baik.

Selanjutnya mitra di berikan pelatihan pembuatan pembukuan sederhana sesuai dengan kebutuhan mitra. Tahapan selanjutnya yaitu Evaluasi kegiatan diarahkan kepada tiga aspek kinerja yakni ; aspek perencanaan, aspek pelaksanaan dan aspek hasil.

\section{KESIMPULAN}

Berdasarkan hasil kegiatan yang sudah dilaksanakan maka dapat disimpulkan sebagai berikut :

1. Pemberian pendidikan dan pelatihan produksi stick wortel dapat meningkatkan pengetahuan dan kemampuan mitra.

2. Mitra sudah dapat memproduksi stick wortel dengan rasa, aroma, dan warna dengan kualitas yang baik.

3. Mitra sudah dapat menggunakan peralatan yang diberikan sehingga jumlah produksi semakin bertambah.

4. Dengan menggunakan kemasan yang baik omset mitra seakin bertambah

\section{UCAPAN TERIMA KASIH}

Ucapan terima kasih kepada Kemenristek Dikti atas pemberian dana hibah tahun 2016 dan terima kasih kepada LPM Unimed serta kepada mitra yang telah membantu dalam pelaksanaan kegiatan ini.

\section{DAFTAR PUSTAKA}

Astarina. 2010. Pengaruh Substitusi Tepung Wortel Pada Pembuatan Biskuit Ditinjau Dari Kadar BKaroten, Sifat Organoleptik Dan Daya Terima. Skripsi. Program Studi S1 Gizi. Fakultas Ilmu Kesehatan Universitas Muhammadiyah Surakarta.

Aguskrisno. 2011. Menu Olahan Wortel Sebagai Alternatif Diet Rendah Kalori Bagi Penderita Obesitas. http:// wordpress.com. Diakses tanggal 18 April 2013.

Pribadi Halim. 2014. Bisnis Keripik Wortel. Diakses tanggal 2 Desember 2014 http :// pribadihaliem. blogspot.co.id

Pantastico E B. 2012. Fsiologi Pasca Panen, Penanganan, Pemanfaatan Buah-buahan dan Sayur-Sayuran Tropika dan Subtropika (terjemahan). UGM Press. Yogyakarta.

Nisa C. 2009. Perbandingan kwalitas wortel dengan cara penanaman pada ujung batang bagian atas dan batang bagian bawah. http://campursariindonesia.blogspot.com.

Wijaya A. 2013. Manfaat, Kandungan Serta Khasiat. http://permathic.blogspot.com. Diakses tanggal 22 April 2013. 